\title{
56. ORGANIC CARBON AND NITROGEN, SEDIMENT COMPOSITION, AND CLAY MINERALOGY OF DEEP SEA DRILLING PROJECT SITE 603, WESTERN ATLANTIC OCEAN ${ }^{1}$
}

\author{
K.-C. Emeis, B. Mycke, H.-H. Richnow, A. Spitzy, and E. T. Degens \\ Geologisch-Paläontologisches Institut, Universität Hamburg ${ }^{2}$
}

\begin{abstract}
Sediment and interstitial water samples recovered during DSDP Leg 93 at Site 603 (lower continental rise off Cape Hatteras) were analyzed for a series of geochemical facies indicators to elucidate the nature and origin of the sedimentary material. Special emphasis was given to middle Cretaceous organic-matter-rich turbidite sequences of Aptian to Turonian age.

Organic carbon content ranges from nil in pelagic claystone samples to $4.2 \%$ (total rock) in middle Cretaceous carbonaceous mudstones of turbiditic origin. The organic matter is of marine algal origin with significant contributions of terrigenous matter via turbidites. Maturation indices (vitrinite reflectance) reveal that the terrestrial humic material is reworked. Maturity of autochthonous material (i.e., primary vitrinite) falls in the range of 0.3 to $0.6 \% \mathrm{R}_{\mathrm{o}}$. Carbohydrate, hydrocarbon, and microscopic investigations reveal moderate to high microbial degradation. Unlike deep-basin black shales of the South and North Atlantic, organic-carbon-rich members of the Hatteras Formation lack trace metal enrichment. Dissolved organic carbon (DOC) in interstitial water samples ranges from $34.4 \mathrm{ppm}$ in a sandstone sample to $126.2 \mathrm{ppm}$ in an organic-matter-rich carbonaceous claystone sample. One to two percent of DOC is carbohydratecarbon.
\end{abstract}

\section{INTRODUCTION}

During DSDP Leg 93, Mesozoic and Cenozoic sediments were drilled to a total depth of $1576 \mathrm{~m}$ at Site 603 on the continental rise off Cape Hatteras on the U.S. east coast. The sedimentary units recognized generally correlate well with lithologic units encountered during previous drilling in the area and are in good agreement with the subdivisions given in Jansa et al. (1979) for the entire western and eastern central Atlantic Ocean (Fig. 1).

The discovery of a Lower Cretaceous turbiditic fan complex incorporating organic-carbon-rich calcareous turbidites of shelf or upper slope origin (Meyers, in press), which are superimposed on a generally pelagic sedimentary facies (Wise et al., in press), assumes importance with regard to the black shale deposits encountered in most deep basins of the Atlantic Ocean (Dean et al., 1984). In a recent study (Degens et al., in press) we discussed characteristic geochemical and facies features of organic-matter-rich sediments laid down in different depocenters of the Atlantic during middle Cretaceous time. We proposed a model to relate shelf, upper slope, and intracratonic black shale sedimentation to the contemporaneous occurrence of deep-basin black shale strata. It was concluded that during a specific stage of tectonic evolution of a passive margin, anoxic basins evolve on the edge of the continent. These basins-graben and half-

\footnotetext{
${ }^{1}$ van Hinte, J. E., Wise, S. W., Jr., et al., Init. Repts. DSDP, 93: Washington (U.S. Govt. Printing Office).

2 Addresses: (Emeis, present address) Ocean Drilling Program, Mail Stop 3469, Texas A\&M University, College Station, TX 77843-3469; (Mycke, Richnow, Spitzy, and Degens) Geologisch-Paläontologisches Institut, Universität Hamburg, Bundesstrasse 55, D-2000 Hamburg 13, Federal Republic of Germany.
}

graben structures generated from crustal stretching (Le Pichon and Sibuet, 1981) - are sediment sources for turbiditic events during tectonically unstable periods or regressions. Primarily pelagic or hemipelagic sedimentation in basins and on the lower continental rise is disrupted by the input of allochthonous, organic-matter-rich material which exhibits specific geochemical and facies properties related to the primary sedimentary regime upslope. One of the cases studied during this attempt to model black shale deposition in different compartments of the continental margin was the sedimentary column drilled at Site 603 during Leg 93. In this chapter, we present mineralogical and geochemical data from all lithological units of Holes 603 and 603B. Our main emphasis is placed on the characterization of organic material in both sediments and interstitial waters. For a discussion of these properties in relation to black shale deposition in deep basins, see Degens et al. (in press).

\section{MATERIALS AND METHODS}

Samples used in this study are listed in Table 1. Lithologic descriptions were adopted from shipboard core descriptions by the Leg 93 shipboard party and, if necessary, modified after visual inspection of samples.

Ground and homogenized sample splits of sediments were subjected to X-ray fluorescence spectroscopy for major- and trace-element composition, and to X-ray diffraction of bulk sediment to monitor mineralogical fluctuations, applying a manual version of the method described by Cook et al. (1975). Total carbon and organic nitrogen $\left(\mathrm{N}_{\text {org }}\right)$ were analyzed with a Carlo Erba Elemental Analyzer. $\mathrm{CaCO}_{3}$ content was measured with a Casumat Model $6 \mathrm{CO}_{2}$ Analyzer, liberating $\mathrm{CO}_{2}$ with $0.1 \mathrm{~N} \mathrm{H}_{3} \mathrm{PO}_{4}$. Difference of total carbon and carbonate carbon was computed as organic carbon $\left(\mathrm{C}_{\mathrm{org}}\right)$. Subsamples of some ground samples were used to prepare kerogen extracts for microscopic investigation of organic matter, its vitrinite reflectance and fluorescence properties. Kerogen was imbedded in epoxy, polished, and measured according to the procedures described in Teichmüller (1982) and 


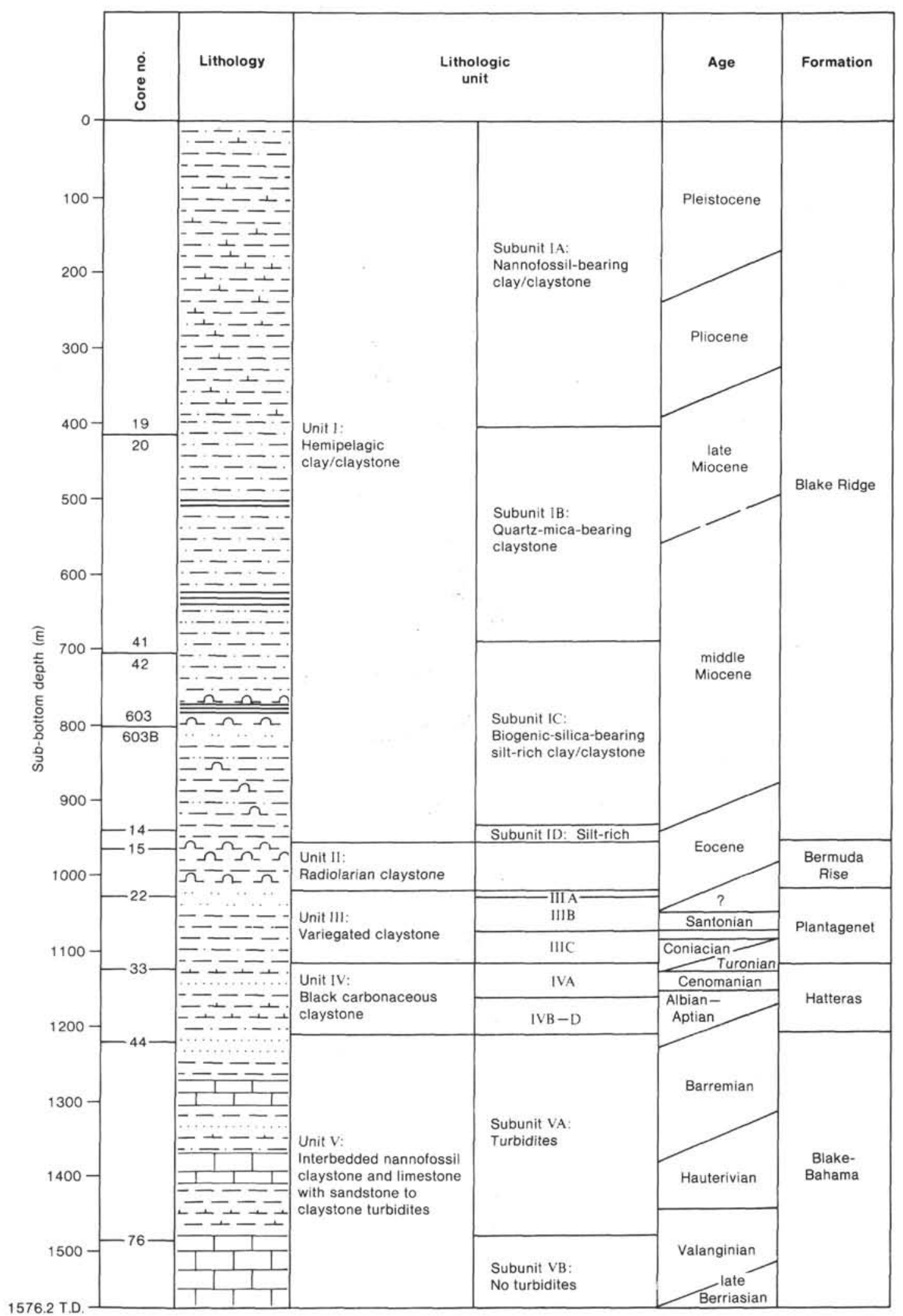

Figure 1. Site 603 core summary. 
Table 1. Samples used in this chapter.

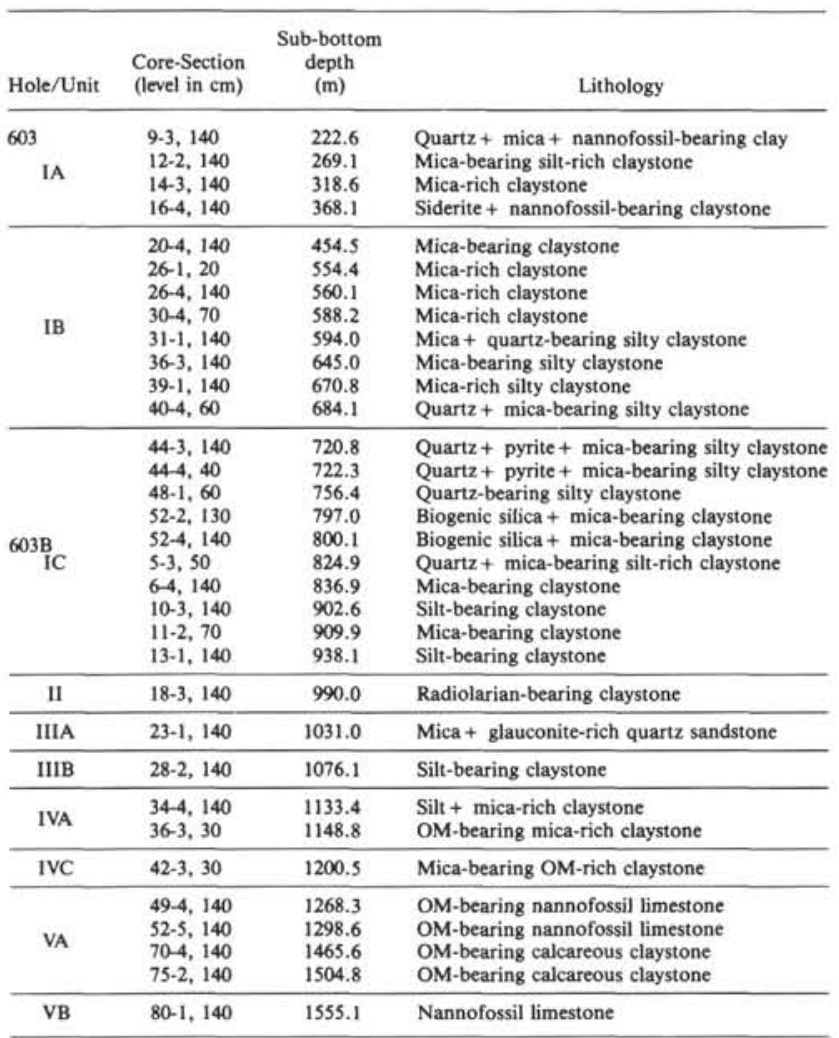

Note: $\mathrm{OM}=$ organic matter.

Ottenjann (1982), using an automated Zeiss analytical microscope. Samples of sediment and interstitial waters were analyzed for carbohydrates $(\mathrm{CH})$ employing the technique described in Mopper (1978). Dissolved organic carbon (DOC) in the interstitial water was measured with a UV oxidation technique. Hydrocarbons $(\mathrm{HC})$ were extracted from ground samples by ultrasonic treatment using toluene/methanol $(3: 1)$. The extracts were purified by liquid chromatography and the hydrocarbon compositions determined by gas chromatography and mass spectroscopy (GC-MS).

\section{GENERAL RESULTS}

\section{Inorganic Geochemistry}

Continuous input of terrigenous clay materials to the lower continental rise throughout the Mesozoic and Cenozoic has produced the uniform lithological pattern of claystones and mudstones drilled at Site 603. The uniformity of sedimentary deposition has resulted in a rather restricted range of both major- and trace-element concentrations in the samples examined in this study. Most of the samples are described as claystones and vary only in the amount and nature of accessory minerals. As a consequence, there is little variation in the amounts of major-element oxides and lithophilic trace elements such as $\mathrm{Al}_{2} \mathrm{O}_{3}, \mathrm{~K}_{2} \mathrm{O}, \mathrm{SiO}_{2}, \mathrm{TiO}_{2}, \mathrm{Rb}, \mathrm{Zr}$, etc., throughout the lithologic column (see Table 2). Major fluctuations appear to be related to variations in the input of carbonate and associated $\mathrm{Sr}$ and to postdepositional preservation or dissolution of carbonates and possibly opal. In the first set of rows of Table 3, giving means and standard deviations of chemical analyses for samples of Hole 603, the ratios of means/standard deviations exceed a critical value of 0.2 only in the cases of $\mathrm{CaO}$ and $\mathrm{Sr}$. With the shallow cores of Hole 603B, variability increases, as expressed by the standard deviations. Most notable are variations in $\mathrm{SiO}_{2}, \mathrm{CaO}$, and the residual trace elements $\mathrm{Zr}$, $\mathrm{V}$, and $\mathrm{Cu}$.

\section{Mineralogy}

Figure 2 summarizes the mineralogical data obtained by X-ray diffraction study of bulk samples. In Units IA and IB, there is little variation in detrital minerals such as quartz, minor feldspars, and the clay minerals illite and kaolinite. In contrast, samples older than middle Miocene show considerable variation in mineralogy, reflecting the impact of changing source areas or different mechanisms of sedimentation. In these older strata, the clay mineral smectite, considered the dominant pelagic clay mineral in the western North Atlantic basin (Chamley et al., 1983), is diluted by detrital illite and kaolinite. Because we did not separate size classes, this may reflect the input of relatively larger clay particles (illite and kaolinite) in the turbiditic processes prevailing throughout the Mesozoic. Increases in illite and kaolinite are associated with an increase in quartz and feldspars. In samples of Unit V, carbonates are the predominant mineral species. The clay mineral associations of Subunit VA display characteristics similar to the younger sediments, where the detrital clay minerals illite and kaolinite dilute background sedimentation of smectite. Sample 603B-30-1, $140-150 \mathrm{~cm}$ from Subunit VB contains only smectite. The presence of over $40 \%$ cristobalite in Sample 603B$18-3,140-150 \mathrm{~cm}$ probably results from the transformation of radiolarian opal, which was converted to cristobalite during compression of sediment to obtain pore water in the laboratory.

\section{Organic Geochemistry}

The organic carbon content in sediments of Late Cretaceous and younger age is generally in the range typical for hemipelagic clays, that is, $0.1-0.5 \% \mathrm{C}_{\text {org }}$. The $\mathrm{C} / \mathrm{N}$ weight ratios are below 8 , corresponding to the ratio of fresh marine material (Redfield et al., 1963). Such low $\mathrm{C} / \mathrm{N}$ ratios may result from adsorption of nitrogen compounds on clay (Müller, 1977). We encountered higher $\mathrm{C}_{\text {org }}$ concentrations with $\mathrm{C} / \mathrm{N}$ ratios of around 8 to 30 only in the carbonaceous claystones of the Hatteras Formation. Carbohydrate analyses show that only a minor amount, less than $1.4 \%$ of the particulate organic fraction, is present as polysaccharides. Most sugar spectra of uniform sediments of Miocene age (Hole 603) are dominated by arabinose and glucose. In older sediments of variable lithologies (Hole 603B samples), glucose is the only dominant individual sugar in some samples, whereas in others, xylose, galactose, and mannose are equivalent in terms of molar percentages (Table 4). Young samples contain up to $70 \mu \mathrm{g}$ of sugars per $\mathrm{g}$ sediment (Sample 603-9-3, $140 \mathrm{~cm}$ at 222.6 m). Sample 603B-36-3, $30 \mathrm{~cm}$, a carbonaceous claystone, was found to be rich in organic carbon, but contained a minimum value (4 $\mu \mathrm{g} / \mathrm{g}$ ) for sugars. As expected, total amounts of sugars are quite low and approach the detection limit of our in- 
Table 2A. Chemical analyses, Hole 603.

\begin{tabular}{|c|c|c|c|c|c|c|c|c|c|c|c|c|c|c|c|c|c|}
\hline & $9-3$ & $12-2$ & $14-3$ & $16-4$ & $20-4$ & $26-1$ & $26-4$ & $30-4$ & $31-1$ & $36 \cdot 3$ & $39-1$ & $40-4$ & $44-3$ & $44-4$ & $48-1$ & $52-2$ & $52-4$ \\
\hline $\mathrm{Na}_{2} \mathrm{O}$ & 1.55 & 1.48 & 1.48 & 1.17 & 1.21 & 1.46 & 1.39 & 1.30 & 1.24 & 1.24 & 1.30 & 1.11 & 1.08 & 1.16 & 1.03 & 1.04 & 1.17 \\
\hline $\mathrm{MgO}$ & 2.52 & 2.59 & 2.62 & 2.48 & 2.35 & 2.44 & 2.43 & 2.32 & 2.18 & 2.29 & 2.71 & 2.41 & 2.35 & 2.35 & 2.50 & 2.51 & 2.50 \\
\hline $\mathrm{Al}_{2} \mathrm{O}_{3}$ & 14.72 & 16.32 & 16.61 & 14.69 & 17.44 & 16.90 & 16.38 & 16.39 & 16.58 & 16.94 & 16.40 & 15.56 & 14.26 & 15.80 & 15.22 & 14.04 & 15.88 \\
\hline $\mathrm{SiO}_{2}$ & 50.40 & 53.93 & 55.56 & 47.73 & 55.47 & 56.30 & 57.31 & 56.27 & 58.09 & 54.91 & 56.40 & 56.12 & 60.57 & 57.53 & 58.32 & 58.52 & 57.22 \\
\hline $\mathrm{P}_{2} \mathrm{O}_{5}$ & 0.14 & 0.14 & 0.16 & 0.15 & 0.12 & 0.11 & 0.12 & 0.11 & 0.10 & 0.10 & 0.14 & 0.16 & 0.20 & 0.10 & 0.19 & 0.18 & 0.12 \\
\hline $\mathrm{SO}_{3}$ & 0.95 & 2.34 & 0.43 & 0.43 & 0.44 & 0.30 & 0.53 & 0.82 & 0.90 & 0.48 & 0.72 & 1.64 & 1.08 & 1.30 & 0.64 & 1.21 & 1.36 \\
\hline $\mathrm{K}_{2} \mathrm{O}$ & 2.69 & 2.94 & 2.88 & 2.63 & 3.07 & 2.74 & 2.75 & 2.80 & 2.76 & 2.83 & 2.65 & 2.59 & 2.26 & 2.46 & 2.42 & 2.15 & 2.47 \\
\hline $\mathrm{CaO}$ & 3.84 & 0.90 & 1.01 & 6.21 & 0.56 & 0.57 & 0.66 & 0.69 & 0.56 & 1,43 & 0.52 & 0.82 & 0.71 & 0.49 & 0.80 & 1.10 & 0.59 \\
\hline $\mathrm{TiO}_{2}$ & 0.71 & 0.77 & 0.76 & 0.67 & 0.80 & 0.79 & 0.77 & 0.79 & 0.78 & 0.75 & 0.75 & 0.75 & 0.66 & 0.77 & 0.72 & 0.66 & 0.75 \\
\hline $\mathrm{Fe}_{2} \mathrm{O}_{3}$ & 7.88 & 7.76 & 6.42 & 6.99 & 6.84 & 6.51 & 6.47 & 6.65 & 6.26 & 6.56 & 6.34 & 6.88 & 5.25 & 6.32 & 5.80 & 5.79 & 6.51 \\
\hline $\operatorname{LOI}^{a^{\circ}}$ & 15.89 & 12.54 & 10.61 & 14.56 & 9.52 & 9.90 & 10.21 & 10.96 & 9.71 & 10.70 & 10.40 & 10.29 & 10.65 & 10.33 & 10.93 & 12.21 & 11.86 \\
\hline Total & 101.28 & 101.72 & 98.55 & 97.72 & 97.82 & 98.02 & 99.02 & 99.10 & 99.16 & 98.23 & 97.98 & 98.33 & 99.06 & 98.62 & 98.58 & 99.40 & 100.42 \\
\hline$C_{\text {total }}$ & 1.29 & 0.61 & 0.65 & 2.01 & 0.58 & 0.46 & 0.46 & 0.67 & 0.53 & 0.85 & 0.57 & 0.74 & 0.98 & 0.57 & 0.85 & 1.07 & 0.66 \\
\hline $\mathrm{C}_{\mathrm{org}}$ & 0.21 & 0.38 & 0.42 & 0.00 & 0.38 & 0.36 & 0.30 & 0.46 & 0.24 & 0.32 & 0.36 & 0.30 & 0.80 & 0.30 & 0.59 & 0.67 & 0.39 \\
\hline Norg & 0.09 & 0.09 & 0.08 & 0.10 & 0.09 & 0.09 & 0.10 & 0.09 & 0.09 & 0.09 & 0.09 & 0.12 & 0.09 & 0.10 & 0.09 & 0.08 & 0.04 \\
\hline $\mathrm{CaCO}_{3}$ & 7.59 & 1.64 & 1.64 & 14.03 & 1.43 & 0.69 & 1.09 & 1.48 & 2.05 & 3.68 & 1.37 & 3.09 & 1.93 & 1.27 & 1.85 & 2.81 & 1.92 \\
\hline $\mathrm{Rb}$ & 119 & 129 & 12 & 11 & 134 & 127 & 125 & 132 & 117 & 130 & 123 & 111 & 106 & 113 & 116 & 106 & 114 \\
\hline Y & 13 & 12 & 18 & 12 & 9 & 15 & 18 & 18 & 13 & 13 & 14 & 18 & 16 & 10 & 16 & 20 & 10 \\
\hline Sr & 217 & 134 & 133 & 292 & 113 & 113 & 110 & 121 & 113 & 137 & 108 & 108 & 113 & 97 & 114 & 121 & 95 \\
\hline $\mathrm{Zr}$ & 127 & 131 & 133 & 113 & 132 & 130 & 137 & 145 & 169 & 128 & 140 & 147 & 134 & 125 & 129 & 130 & 120 \\
\hline
\end{tabular}

Note: Sample numbers are cores and sections only. For sub-bottom depths see Table 1. Except for $\mathrm{Rb}, \mathrm{Y}, \mathrm{Sr}$, and $\mathrm{Zr}$ (ppm), all values are weight percentages of bulk sample. $\mathrm{C}_{\text {org }}$ and

$\mathrm{N}_{\text {org }}$ were determined on carbonate-free residue after $\mathrm{HCl}$ leaching.
${ }^{\mathrm{LOI}}=$ Weight loss on ignition at $950^{\circ} \mathrm{C}$.

Table 2B. Chemical analyses, Hole 603B.

\begin{tabular}{|c|c|c|c|c|c|c|c|c|c|c|c|c|c|c|c|}
\hline & $5-3$ & $6-4$ & $10-3$ & $11-2$ & $13-1$ & $18-3$ & $23-1$ & $28-2$ & $34-4$ & $36-3$ & $42-3$ & $49-4$ & $52-5$ & $75-2$ & $80-1$ \\
\hline $\mathrm{Na}_{2} \mathrm{O}$ & 2.11 & 2.51 & 1.21 & 1.06 & 1.30 & 1.15 & 0.63 & 0.97 & 1.29 & 1.57 & 1.25 & 0.32 & 0.57 & 0.93 & 0.00 \\
\hline $\mathrm{MgO}$ & 2.70 & 1.26 & 2.44 & 2.45 & 2.26 & 1.88 & 0.44 & 1.81 & 1.87 & 1.06 & 2.52 & 1.07 & 1.29 & 1.83 & 1.01 \\
\hline $\mathrm{Al}_{2} \mathrm{O}_{3}$ & 12.04 & 12.79 & 15.00 & 15.72 & 13.77 & 15.18 & 5.56 & 19.20 & 16.52 & 9.73 & 14.47 & 5.39 & 5.90 & 17.09 & 3.63 \\
\hline $\mathrm{SiO}_{2}$ & 40.65 & 68.21 & 60.82 & 58.18 & 62.45 & 60.97 & 84.78 & 55.27 & 59.59 & 64.36 & 54.45 & 16.09 & 19.19 & 43.72 & 12.74 \\
\hline $\mathrm{P}_{2} \mathrm{O}_{5}$ & 0.16 & 0.10 & 0.14 & 0.12 & 0.17 & 0.17 & 0.14 & 0.06 & 0.08 & 0.13 & 0.14 & 0.08 & 0.09 & 0.05 & 0.06 \\
\hline $\mathrm{SO}_{3}$ & 0.88 & 0.55 & 0.43 & 0.94 & 0.66 & 0.00 & 0.00 & 0.00 & 0.02 & 3.01 & 0.97 & 1.39 & 2.19 & 1.51 & 0.72 \\
\hline $\mathrm{K}_{2} \mathrm{O}$ & 2.74 & 2.61 & 2.21 & 2.26 & 2.07 & 2.25 & 2.44 & 2.45 & 2.19 & 1.91 & 2.33 & 1.07 & 0.98 & 2.26 & 0.61 \\
\hline $\mathrm{CaO}$ & 14.29 & 1.58 & 0.59 & 1.48 & 0.67 & 0.50 & 0.32 & 0.35 & 0.52 & 0.50 & 0.96 & 36.54 & 34.21 & 10.24 & 40.64 \\
\hline $\mathrm{TiO}_{2}$ & 0.60 & 0.82 & 0.68 & 0.70 & 0.68 & 0.65 & 0.80 & 0.89 & 0.86 & 0.46 & 0.71 & 0.25 & 0.26 & 0.72 & 0.16 \\
\hline $\mathrm{Fe}_{2} \mathrm{O}_{3}$ & 5.36 & 3.96 & 5.08 & 5.34 & 5.05 & 5.25 & 1.72 & 6.54 & 5.75 & 3.30 & 6.76 & 2.41 & 2.97 & 5.82 & 1.76 \\
\hline $\mathrm{LOI}^{\mathrm{a}^{\mathrm{a}}}$ & 17.34 & 5.19 & 10.12 & 10.64 & 9.39 & 9.88 & 1.64 & 11.1 & 9.67 & 14.72 & 13.76 & 34.78 & 31.86 & 17.09 & 36.17 \\
\hline Total & 98.72 & 99.56 & 98.72 & 98.88 & 98.46 & 97.83 & 98.42 & 98.56 & 98.37 & 100.72 & 98.30 & 99.40 & 99.52 & 101.27 & 97.43 \\
\hline $\mathrm{CaCO}_{3}$ & 25.36 & 2.01 & 1.04 & 2.54 & 1.65 & 0.17 & 0.23 & 0.29 & 0.29 & 0.41 & 3.71 & 75.74 & 63.02 & 19.15 & 72.38 \\
\hline $\mathrm{Mn}$ & 0.16 & 0.05 & 0.16 & 0.07 & 0.10 & 0.07 & 0.03 & 0.06 & 0.03 & 0.02 & 0.80 & 0.10 & 0.04 & 0.04 & 0.23 \\
\hline$C_{\text {total }}$ & 3.21 & 0.36 & 0.43 & 0.94 & 0.60 & 0.15 & 0.04 & 0.14 & 0.21 & 1.67 & 3.71 & 10.32 & 8.69 & 3.06 & 9.99 \\
\hline $\mathrm{C}_{\text {org }}$ & 0.10 & 0.36 & 0.28 & 0.58 & 0.37 & 0.13 & 0.10 & 0.10 & 0.17 & 1.61 & 3.18 & 0.50 & 0.10 & 0.32 & 0.10 \\
\hline$N_{\text {org }}$ & 0.07 & 0.07 & 0.10 & 0.10 & 0.08 & 0.07 & 0.01 & 0.04 & 0.03 & 0.08 & 0.11 & 0.11 & 0.06 & 0.04 & 0.12 \\
\hline $\mathrm{Ba}$ & 551 & 506 & 398 & 380 & 441 & 331 & 349 & 324 & 394 & 408 & 374 & 116 & 113 & 339 & 17 \\
\hline v & 131 & 76 & 175 & 156 & 158 & 113 & 31 & 129 & 95 & 162 & 231 & 93 & 104 & 109 & 25 \\
\hline $\mathrm{Cr}$ & 71 & 57 & 102 & 102 & 95 & 174 & 69 & 118 & 93 & 124 & 150 & 60 & 41 & 86 & 18 \\
\hline $\mathrm{Sc}$ & 24 & 2 & 20 & 21 & 14 & 21 & 5 & 23 & 23 & 21 & 14 & 43 & 43 & 21 & 46 \\
\hline $\mathrm{La}$ & 15 & 16 & 36 & 31 & 25 & 31 & 41 & 16 & 20 & 27 & 23 & 8 & 4 & 9 & 3 \\
\hline $\mathrm{Ce}$ & 57 & 95 & 79 & 64 & 83 & 87 & 106 & 120 & 72 & 71 & 76 & 38 & 35 & 40 & 13 \\
\hline Nd & 25 & 29 & 26 & 29 & 32 & 34 & 50 & 36 & 41 & 39 & 44 & 4 & 6 & 14 & 7 \\
\hline $\mathrm{Ni}$ & 47 & 44 & 54 & 69 & 59 & 103 & 13 & 37 & 55 & 56 & 67 & 42 & 41 & 80 & 29 \\
\hline $\mathrm{Cu}$ & 72 & 16 & 77 & 75 & 74 & 729 & 8 & 48 & 287 & 46 & 230 & 107 & 129 & 62 & 57 \\
\hline $\mathrm{Zn}$ & 89 & 64 & 99 & 111 & 99 & 112 & 23 & 92 & 78 & 91 & 163 & 137 & 95 & 90 & 38 \\
\hline $\mathrm{Rb}$ & 104 & 87 & 106 & 110 & 94 & 116 & 81 & 131 & 118 & 111 & 116 & 48 & 50 & 124 & 24 \\
\hline Y & 17 & 47 & 5 & 14 & 11 & 17 & 69 & 9 & 16 & 20 & 22 & 35 & 33 & 8 & 21 \\
\hline $\mathrm{Sr}$ & 589 & 197 & 106 & 136 & 108 & 133 & 61 & 136 & 197 & 194 & 219 & 581 & 650 & 391 & 601 \\
\hline $\mathrm{Zr}$ & 75 & 325 & 107 & 116 & 139 & 94 & 914 & 132 & 157 & 123 & 104 & 37 & 30 & 80 & 10 \\
\hline
\end{tabular}

Note: Sample numbers are cores and sections only. For sub-bottom depths see Table 1. Trace elements Ba through $\mathrm{Zr}$ are given in ppm, all others in weight percent-

${ }^{\text {a }} \mathrm{LOI}=$ Loss on ignition at $950^{\circ} \mathrm{C}$.

strument. However, duplicate analyses revealed good reproducibility in both relative and absolute abundances. (Data for hydrocarbon analyses of sediment extracts are given later in Table 8 and Figure 7.)

The DOC values for pore waters are given in Table 5 . Highest values are present in the organic-matter-rich car- bonaceous claystones; the lowest value is recorded in a quartz sandstone member of Unit IIIA (Upper Cretaceous). Carbohydrates in the interstitial waters of Miocene claystones are dominated by glucose, fructose, and arabinose. In pore waters of older sediments, contributions of galactose, mannose, and xylose increase. About 
Table 3. Means and standard deviations for main and trace elements of sediments from Holes 603 and 603B.

\begin{tabular}{|c|c|c|c|c|c|c|c|c|}
\hline & \multicolumn{4}{|c|}{ Hole $603(N=16)$} & \multicolumn{4}{|c|}{ Hole 603B $(N=17)$} \\
\hline & Mean & S.D. & Max. & Min. & Mean & S.D. & Max. & Min. \\
\hline \multicolumn{9}{|l|}{ Oxides $(\%)$} \\
\hline $\mathrm{Na}_{2} \mathrm{O}$ & 1.26 & 0.16 & 1.55 & 1.03 & 1.14 & 0.59 & 2.51 & 0.00 \\
\hline $\mathrm{MgO}$ & 2.44 & 0.13 & 2.59 & 2.18 & 1.69 & 0.67 & 2.70 & 0.44 \\
\hline $\mathrm{Al}_{2} \mathrm{O}_{3}$ & 15.89 & 1.00 & 17.44 & 14.04 & 12.07 & 5.25 & 19.20 & 3.63 \\
\hline $\mathrm{SiO}_{2}$ & 55.92 & 3.05 & 60.57 & 47.73 & 49.35 & 20.51 & 84.78 & 12.74 \\
\hline $\mathrm{P}_{2} \mathrm{O}_{5}$ & 0.14 & 0.03 & 0.20 & 0.10 & 0.13 & 0.11 & 0.17 & 0.05 \\
\hline $\mathrm{SO}_{3}$ & 0.92 & 0.53 & 2.34 & 0.30 & 1.19 & 0.88 & 3.01 & 0.00 \\
\hline $\mathrm{K}_{2} \mathrm{O}$ & 2.65 & 0.24 & 3.07 & 2.15 & 1.95 & 0.67 & 2.74 & 0.61 \\
\hline $\mathrm{CaO}$ & 1.26 & 1.50 & 3.84 & 0.49 & 10.59 & 15.51 & 40.64 & 0.32 \\
\hline $\mathrm{TiO}_{2}$ & 0.74 & 0.05 & 0.80 & 0.66 & 0.60 & 0.25 & 0.89 & 0.16 \\
\hline $\mathrm{Fe}_{2} \mathrm{O}_{3}$ & 6.54 & 0.65 & 7.88 & 5.25 & 4.39 & 1.74 & 6.76 & 1.72 \\
\hline \multicolumn{9}{|c|}{ Elements (ppm) } \\
\hline $\mathrm{Rb}$ & 120 & 9 & 134 & 106 & 90 & 33 & 131 & 24 \\
\hline Y & 14 & 3 & 18 & 9 & 21 & 16 & 69 & 5 \\
\hline St & 132 & 49 & 217 & 95 & 313 & 194 & 650 & 61 \\
\hline $\mathrm{Zr}$ & 134 & 12 & 169 & 113 & 148 & 210 & 914 & 10 \\
\hline $\mathrm{Ba}$ & n.d. & n.d. & & & 386 & 329 & 551 & 17 \\
\hline v & n.d. & n.d. & & & 151 & 160 & 231 & 25 \\
\hline $\mathrm{Cr}$ & n.d. & n.d. & & & 87 & 42 & 150 & 18 \\
\hline $\mathrm{La}$ & n.d. & n.d. & & & 20 & 12 & 41 & 3 \\
\hline $\mathrm{Ce}$ & n.d. & n.d. & & & 64 & 31 & 120 & 13 \\
\hline Nd & n.d. & n.d. & & & 26 & 15 & 50 & 4 \\
\hline $\mathrm{Ni}$ & n.d. & n.d. & & & 56 & 28 & 103 & 13 \\
\hline $\mathrm{Cu}$ & n.d. & n.d. & & & 132 & 170 & 729 & 8 \\
\hline $\mathrm{Zn}$ & n.d. & n.d. & & & 98 & 53 & 163 & 23 \\
\hline
\end{tabular}

Note: n.d. $=$ not determined. S.D. $=$ standard deviation

$1-2 \%$ of the DOC is accounted for by carbohydrates (see Table 6).

\section{Petrography of Particulate Carbon Compounds}

Seven kerogen samples were analyzed for their maceral composition and maturity by vitrinite reflectance determinations. They represent lithologies from Hole 603B and encompass claystones, carbonaceous mud turbidites, and limestones. In all samples, macerals of the liptinite group, that is, material of marine origin, are the most abundant, with bituminite dominating (Fig. 3). The term bituminite is used here to include all amorphous material that is gray to reddish brown in color in reflected light and shows weak to moderate, grayish to orange fluorescence when excited with light of $365 \mathrm{~nm}$ wavelength. Bituminite, which is usually subdivided into several subcategories (see Teichmüller and Ottenjann, 1977), is believed to originate from microbial degradation of mainly algal material or to be the remains of the bacteria themselves. It usually contains large amounts of framboidal pyrite. Under the light microscope with high magnification, bituminite assumes a grainy texture, with bits of algal substances visible. It is also referred to as kerogen I (Gutjahr, 1980) and is a precursor of oil. Present in notable amounts were also alginite (bodies, colonies, or detritus of marine algae, which are sometimes laminated, clustered, or aggregated and exhibit vivid yellow to brown fluorescence) and macerals derived from land plants. These include vitrinites showing variable reflectance and texture that indicate recycling and redeposition after thermal diagenesis in a different depositional regime, and inertinite material of very high reflectance and maturity. In samples of the turbiditic Hatteras Formation, these land-derived materials accounted for up to $40 \%$ of the kerogen samples, whereas they were almost absent in marine, autochthonous claystones and limestones of Cenozoic and Mesozoic strata. Reflectance measurements of vitrinite resulted in wide ranges of $R_{0}$ values (Table 7).

\section{DISCUSSION}

\section{Inorganic Geochemistry}

We performed cluster analysis with the data pool of Table 2 in order to establish the degree of interrelation between certain elements and oxides. Figure 4 shows the resulting dendrogram. Parameters are grouped with ascending correlation along the $\mathrm{X}$-axis. The close relationship of (1) oxides forming sheet silicates such as smectite, illite, and kaolinite $\left(\mathrm{Na}_{2} \mathrm{O}, \mathrm{SiO}_{2}, \mathrm{~K}_{2} \mathrm{O}, \mathrm{MgO}, \mathrm{Al}_{2} \mathrm{O}_{3}\right.$, and $\mathrm{Fe}_{2} \mathrm{O}_{3}$, including the lithophilic element $\mathrm{Rb}$ and $\mathrm{TiO}_{2}$ ) is easily recognized. Other groups significant on the $5 \%$ level (for $N=32$ samples, the significant value of the correlation coefficient is higher than 0.3494, after Überla, 1977) are: (2) $\mathrm{C}_{\text {org }}$ and $\mathrm{SO}_{3}$; and (3) the carbonatedominated group $\mathrm{CaO}, \mathrm{Sr}$, and $\mathrm{Mn}$ (including other expressions of carbonate content like loss on ignition, total $\mathrm{C}$, or $\mathrm{CaCO}_{3}$ ). Of other groups considered, (4) $\mathrm{Y}$ and $\mathrm{Zr}$ are indicators of terrestrially derived heavy minerals present in the samples. Finally, (5) we interpret the cluster including most trace elements ( $\mathrm{Ba}, \mathrm{V}, \mathrm{Ni}, \mathrm{Zn}, \mathrm{Cr}, \mathrm{Ce}$, $\mathrm{La}, \mathrm{Cu})$ as a residual group of elements.

Pelagic or hemipelagic claystones of average composition when compared to standard clay are diluted with sporadic inputs of carbonaceous material in Lower and middle Cretaceous sediments. The trace elements $\mathrm{V}, \mathrm{Ni}$, $\mathrm{Zn}, \mathrm{Cu}$, and the rare earth elements are not enriched in sulfides, clays, or carbonates. The trace elements correlate significantly with $\mathrm{Ba}$, enrichment in which is believed to indicate times of nondeposition or sediment starvation (Brumsack, pers. comm., 1984).

This resemblance may be interpreted in two ways. One is to assume diagenetic effects: remobilization in the uncompacted sediments as a result of a changing $\mathrm{pH} / \mathrm{Eh}$ regime and migration in pore waters with subsequent enrichment at the sediment/water interface (Graybeal and Heath, 1984). Another, more speculative assumption (which cannot be tested with our results because of the inadequate analytical techniques employed for phosphorus determination), is that apatite is frequently associated with diagenetically precipitated barium sulfate in many deep-sea sediments (e.g., Leg 75, Angola Basin; Emeis, 1985). Apatite- and barium-rich strata may be sinks of many trace elements (Wedepohl, 1978). In a study of pelagic and hydrothermally influenced sediments, Leinen and Pisias (1983) employed normative and statistical methods to discriminate between different sources for a sedimentary unit. They found interelement correlations similar to our results from cluster analysis. They labeled the cluster of elements embracing $\mathrm{Ba}, \mathrm{V}, \mathrm{Cr}, \mathrm{Ni}$, $\mathrm{Cu}$ and the rare earth elements as "residual" and argued that these elements will be enriched as dissolution products of biogenic opaline and carbonate material. This is in agreement with our observations, because these elements behave independently of either carbonate, detrital, or organic parameters. In the carbonate-rich turbi- 


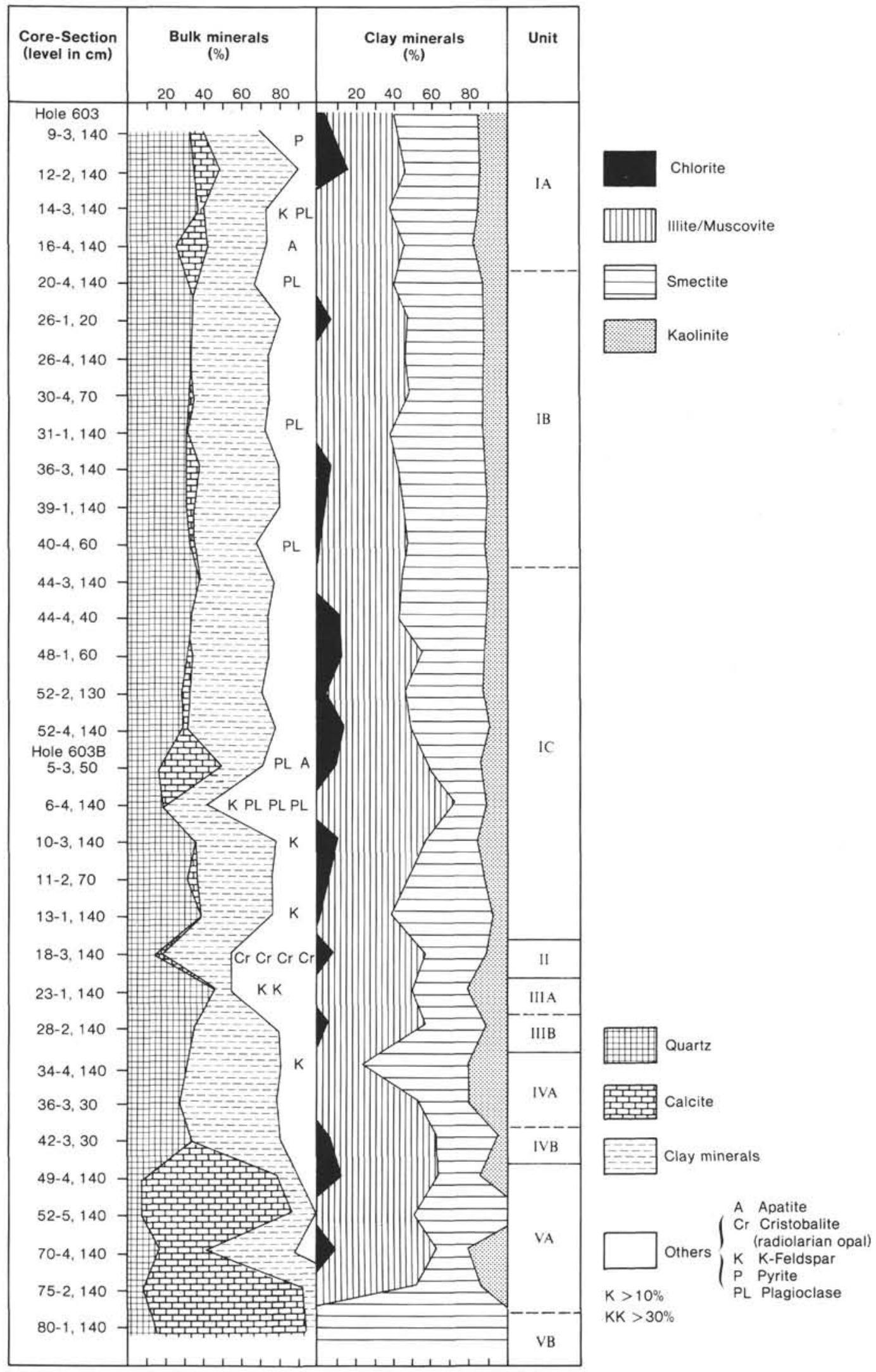

Figure 2. Relative composition of mineral assemblages in sediments drilled at Site 603 (X-ray diffraction of bulk sample). For sample depths and lithologies, see Table 1. 
Table 4. Distribution of carbohydrates in sediments from Holes 603 and 603B.

\begin{tabular}{|c|c|c|c|c|c|c|c|c|c|c|c|c|c|}
\hline & \multicolumn{5}{|c|}{ Hole 603} & \multicolumn{8}{|c|}{ Hole 603B } \\
\hline & $9-3$ & $26-1$ & $26-4$ & $39-1$ & $40-4$ & $6-4$ & $10-3$ & $13-1$ & $23-1$ & $34-4$ & $36-3$ & $42-3$ & $52-5$ \\
\hline Rha & 6.1 & 0.0 & 1.7 & 0.0 & 1.9 & 11.7 & 0.0 & 0.0 & 0.0 & 0.0 & 0.3 & 0.0 & 0.0 \\
\hline Rib & 16.3 & 0.0 & 2.1 & 0.0 & 7.9 & 3.3 & 0.0 & 0.0 & 0.0 & 0.0 & 0.3 & 0.0 & 0.0 \\
\hline Man & 13.3 & 7.0 & 2.7 & 6.2 & 4.1 & 9.8 & 5.1 & 0.0 & 11.6 & 14.8 & 9.7 & 0.0 & 1.9 \\
\hline Fru & 5.2 & 7.5 & 5.0 & 9.1 & 12.2 & 4.0 & 12.1 & 28.1 & 23.8 & 3.0 & 8.6 & 35.7 & 11.2 \\
\hline Ara & 21.3 & 44.3 & 17.8 & 20.1 & 8.3 & 7.5 & 6.1 & 3.4 & 6.0 & 7.7 & 8.7 & 11.9 & 8.1 \\
\hline Fuc & 0.0 & 0.0 & 2.0 & 0.0 & 0.0 & 10.2 & 1.1 & 0.0 & 4.4 & 2.4 & 2.0 & 0.0 & 0.0 \\
\hline Gal & 14.1 & 0.0 & 2.8 & 3.3 & 1.7 & 17.8 & 4.3 & 3.8 & 6.1 & 19.5 & 14.2 & 3.4 & 6.3 \\
\hline Xyl & 12.5 & 1.5 & 3.6 & 7.2 & 4.1 & 19.2 & 12.1 & 7.1 & 7.9 & 9.6 & 11.6 & 2.2 & 13.1 \\
\hline Glc & 11.2 & 39.7 & 62.3 & 54.2 & 59.9 & 16.5 & 59.2 & 57.6 & 40.2 & 43.0 & 44.7 & 46.8 & 59.4 \\
\hline Total & 70.8 & 9.5 & 23.5 & 17.1 & 20.9 & 48.7 & 10.7 & 25.8 & 14.0 & 61.0 & 4.4 & 10.1 & 7.0 \\
\hline
\end{tabular}

Note: Sample numbers are cores and sections only. For sub-bottom depths see Table 1. Individual sugars are given in mol\%; total $\mathrm{CH}$ are given in $\mu \mathrm{g} / \mathrm{g}$ sediment. Rha $=$ Rhamnose, $\mathrm{Rib}=$ Ribose, Man $=$ Mannose, Fru $=$ Fructose, Ara $=$ Arabinose, Fuc $=$ Fucose, $\mathrm{Gal}=$ Galactose, $\mathrm{Xyl}=$ Xylose, Glc $=$ Glucose.

Table 5. Interstitial water samples and dissolved organic carbon (DOC) in interstitial water samples.

\begin{tabular}{lccc}
\hline & Sub-bottom & & \\
$\begin{array}{c}\text { Sample no. } \\
\text { (level in cm) }\end{array}$ & $\begin{array}{c}\text { depth } \\
(\mathrm{m})\end{array}$ & $\begin{array}{c}\text { DOC } \\
\text { (ppm) }\end{array}$ & $\begin{array}{c}\mathrm{C}_{\text {org }}(\%) \\
\text { (sed.) }\end{array}$ \\
\hline Hole 603 & & & \\
& & & \\
$9-3,140$ & 222.6 & 74.1 & 0.21 \\
$12-2,140$ & 269.1 & 84.2 & 0.38 \\
$14-3,140$ & 318.6 & 87.8 & 0.42 \\
$20-4,140$ & 454.5 & 78.0 & 0.38 \\
$31-1,140$ & 594.0 & 72.7 & 0.24 \\
$36-3,140$ & 645.0 & 47.8 & 0.32 \\
$39-1,140$ & 670.8 & 49.7 & 0.36 \\
$44-3,140$ & 720.8 & 54.6 & 0.80 \\
$52-4,140$ & 800.1 & 61.2 & 0.39
\end{tabular}

Hole 603B

$\begin{array}{rrrr}13-1,140 & 938.1 & 57.4 & 0.37 \\ 18-3,140 & 990.0 & 55.5 & 0.13 \\ 23-1,140 & 1031.0 & 34.4 & 0.10 \\ 28-2,140 & 1076.1 & 112.8 & 0.10 \\ 64-4,140 & 1411.6 & 126.2 & \text { n.d. }\end{array}$

Table 6. Distribution of carbohydrates in interstitial water.

\begin{tabular}{|c|c|c|c|c|c|c|c|c|}
\hline \multirow[b]{2}{*}{ Sample } & \multicolumn{2}{|c|}{ Hole 603} & \multicolumn{6}{|c|}{ Hole $603 \mathrm{~B}$} \\
\hline & $31-1$ & $36-3$ & $13-1$ & $18-1$ & $23-1$ & $28-2$ & $49-4$ & $70-4$ \\
\hline Man & 1.7 & 2.6 & 10.6 & 12.0 & 5.2 & 2.7 & n.d. & 9.5 \\
\hline Fru & 32.4 & 39.2 & 13.1 & 12.0 & 18.5 & 19.9 & n.d. & 19.5 \\
\hline Ara & 35.2 & 41.4 & 25.1 & 18.8 & 21.2 & 35.2 & n.d. & 14.5 \\
\hline Fuc & 0.0 & 0.0 & 0.0 & 4.4 & 0.4 & 0.0 & n.d. & 0.1 \\
\hline $\mathrm{Gal}$ & 0.1 & 2.9 & 8.7 & 6.7 & 15.7 & 3.1 & n.d. & 7.2 \\
\hline Xyl & 0.7 & 2.0 & 7.4 & 16.2 & 0.7 & 5.4 & n.d. & 11.0 \\
\hline Glc & 29.9 & 11.8 & 35.0 & 29.9 & 38.3 & 33.6 & n.d. ${ }^{a}$ & 38.2 \\
\hline Total & 1.1 & 0.8 & 2.5 & 2.5 & 2.6 & 2.5 & $2.3^{\mathrm{a}}$ & 3.8 \\
\hline
\end{tabular}

Note: Samples are cores and sections only. For sub-bottom depths see Table 1. Individual $\mathrm{CH}$ are given in $\mathrm{mol} \%$; total $\mathrm{CH}$ is given in $\mu \mathrm{g}$ / $\mathrm{ml}$ interstitial water. Symbols as in Table 4 .

a Only glucose was detected in the sample.

ditic material, these elements may be transported with remains of algae or in the carbonate fraction. Under conditions of carbonate and opal undersaturation in deep water, some of this material will be dissolved; trace elements will be transported toward the sediment/water in- terface with the pore water and will be precipitated and enriched at appropriate geochemical interfaces.

\section{Organic Geochemistry}

\section{DOC}

From a plot of DOC and $\mathrm{C}_{\text {org }}$ in the corresponding sediment versus depth (Fig. 5) it appears that lithologies and the organic matter contained in the sediments determine DOC concentrations in interstitial waters. Three discrete regimes of DOC in pore waters become apparent in Figure 5. The organic-matter-rich samples of middle Cretaceous turbidite sequences exhibit high values. DOC concentrations decrease abruptly by $50 \%$ within several meters of the sediment at the lithologic change to claystones low in organic matter. The concentrations stay uniformly low for about $200 \mathrm{~m}$. Then, without any obvious lithological or chemical change, a distinct elevation of DOC content is recorded in Subunit IB and steadily increases to the youngest samples. We interpret the shape of this curve as an indication that migration or diffusion of DOC away from its kerogen source with pore waters will not level out the differences in DOC generated by adjacent sediments. This implies that even in Mesozoic sediments the rate of DOC production from kerogen is higher than loss of DOC by diffusion/migration. Exclusion of high values for the organic-carbon-rich strata from a computation of the regression of DOC versus depth yields a correlation coefficient of -0.8194 , which is significant at the $1 \%$ error level. This regression line is described by equation 1 :

$$
X_{\mathrm{DOC}}=-0.048 \times Y_{\mathrm{depth}}+93.64
$$

The DOC concentration in pore waters decreases by 0.05 ppm per meter of burial (uncorrected for compaction). The DOC concentrations extrapolated for the sediment/water interface would be $94 \mathrm{ppm}$, which is not altogether unrealistic.

\section{Carbohydrates}

Indicators for input of marine or terrestrial organic matter are hydrocarbons, carbohydrates, and maceral groups derived from land plants. In recent sediments, 
Core-Section (level in $\mathrm{cm}$ )

$10-3,140$

$36-3,30$

$36-3,40$

$42-3,30$

$75-2,140$

암

$80-1,140$

$$
R_{\text {oil }}(\%)
$$
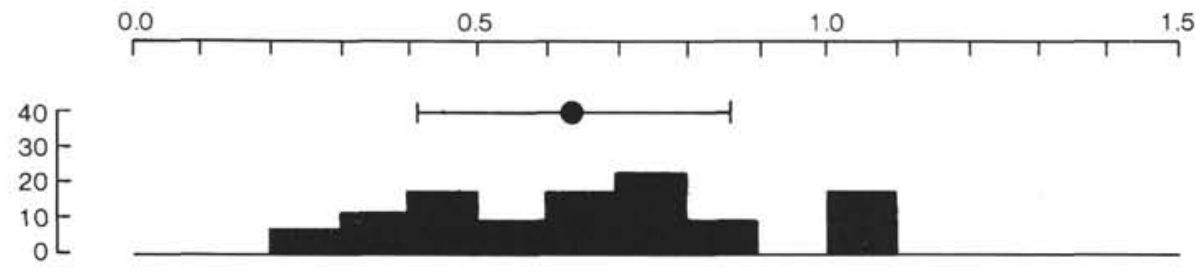

$$
{ }_{0}^{40}{ }_{0}^{30}[-
$$

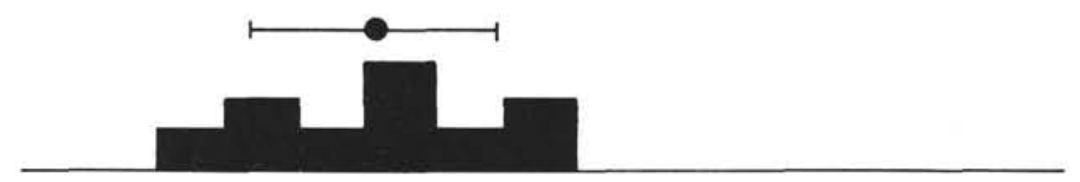

30
30
20
10
0
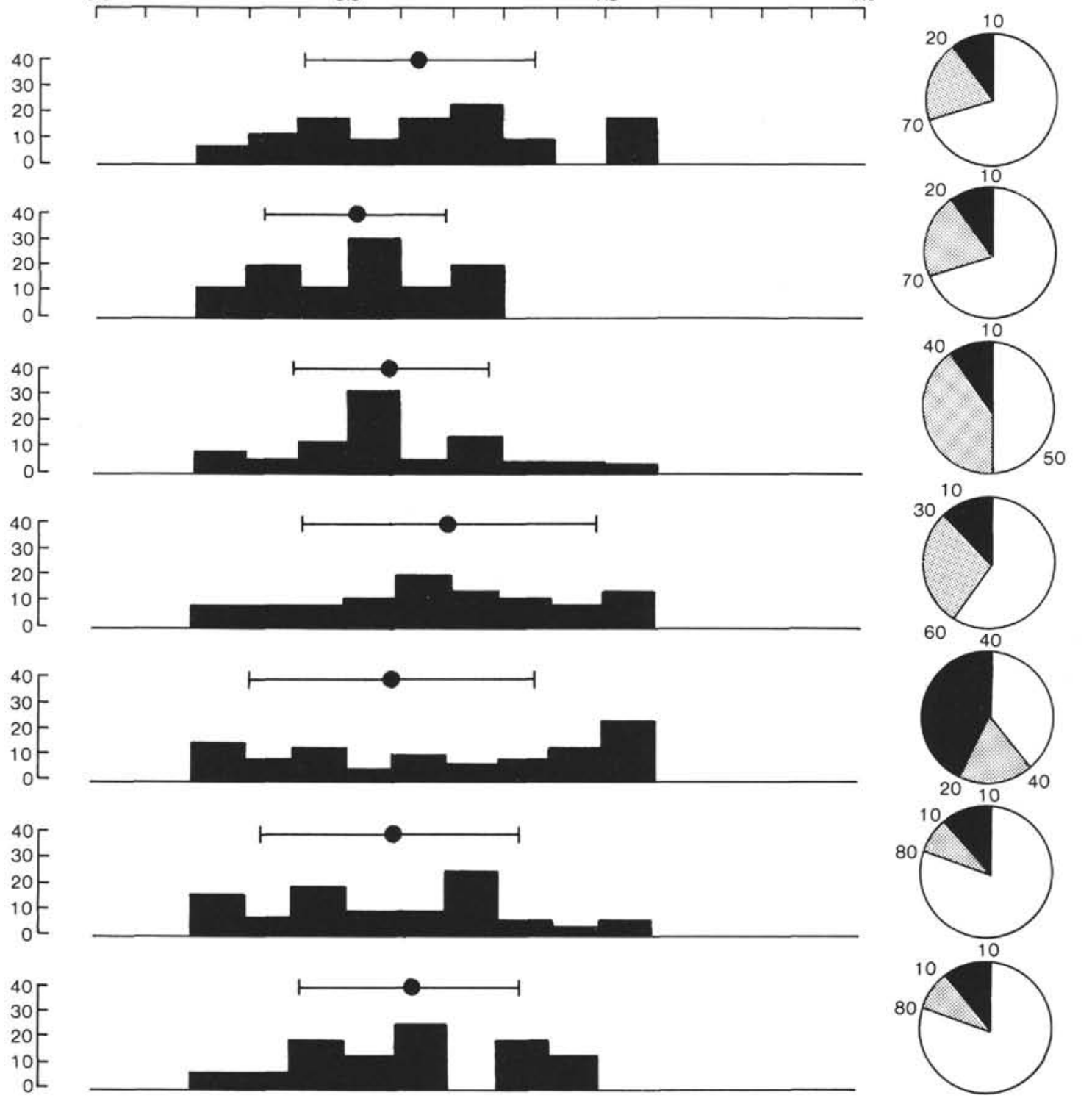

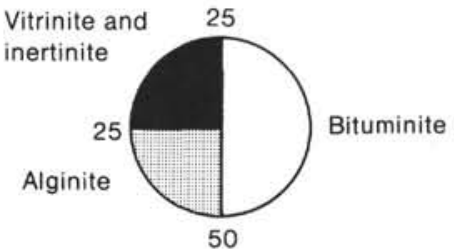

Relative abundance

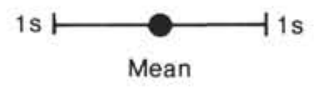

Figure 3. Results of vitrinite reflectance measurements and maceral composition of kerogen extracts. For sample depths and lithologies, see Table 1.

carbohydrates $(\mathrm{CH})$ and proteinaceous material are the dominant constituents of organic matter. Both may account for up to $10 \%$ of the nonkerogenous $\mathrm{C}_{\text {org }}$ (Tanoue and Handa, 1979; Degens et al., 1980). The range of $\mathrm{CH}$-carbon contribution to $\mathrm{C}_{\mathrm{org}}$ in sediments of Holes 603 and 603B never exceeds $1.4 \%$, a fact that has been observed in other studies (Michaelis et al., 1982; Mycke et al., 1986). Consequently, the fresh material containing carbohydrates must be rather labile and is altered or consumed in diagenetic processes during burial.

Three possible reasons for the decay of polysaccharides are conceivable: (1) microbial consumption, (2) release of carbohydrates to the dissolved organic carbon pool of the interstitial water, and (3) incorporation into 
Table 7. Means and standard deviations of vitrinite reflectance, Hole 603B.

\begin{tabular}{lccccc}
\hline $\begin{array}{c}\text { Core-Section } \\
\text { (level in cm) }\end{array}$ & $\begin{array}{c}\text { Sub-bottom } \\
\text { depth } \\
(\mathrm{m})\end{array}$ & Mean Roil & S.D. & $\begin{array}{c}\text { Variation } \\
(\%)\end{array}$ & $N^{\mathrm{a}}$ \\
\hline $10-3,140$ & 902.6 & 0.63 & 0.23 & 36 & 38 \\
$13-1,140$ & 938.1 & 0.51 & 0.18 & 36 & 15 \\
$36-3,30$ & 1148.7 & 0.58 & 0.19 & 32 & 30 \\
$36-3,40$ & 1148.8 & 0.70 & 0.29 & 41 & 30 \\
$42-3,30$ & 1200.5 & 0.59 & 0.27 & 46 & 48 \\
$75-2,140$ & 1504.8 & 0.59 & 0.25 & 43 & 32 \\
$80-1,140$ & 1555.1 & 0.63 & 0.21 & 33 & 16 \\
\hline
\end{tabular}

${ }^{\mathrm{a}} \mathrm{N}=$ number of measuring points.

b Sample 603B-36-3, $40 \mathrm{~cm}$ is a claystone subsample low in $\mathrm{C}_{\text {org }}$, from 603B-36-3, 30-40 cm.

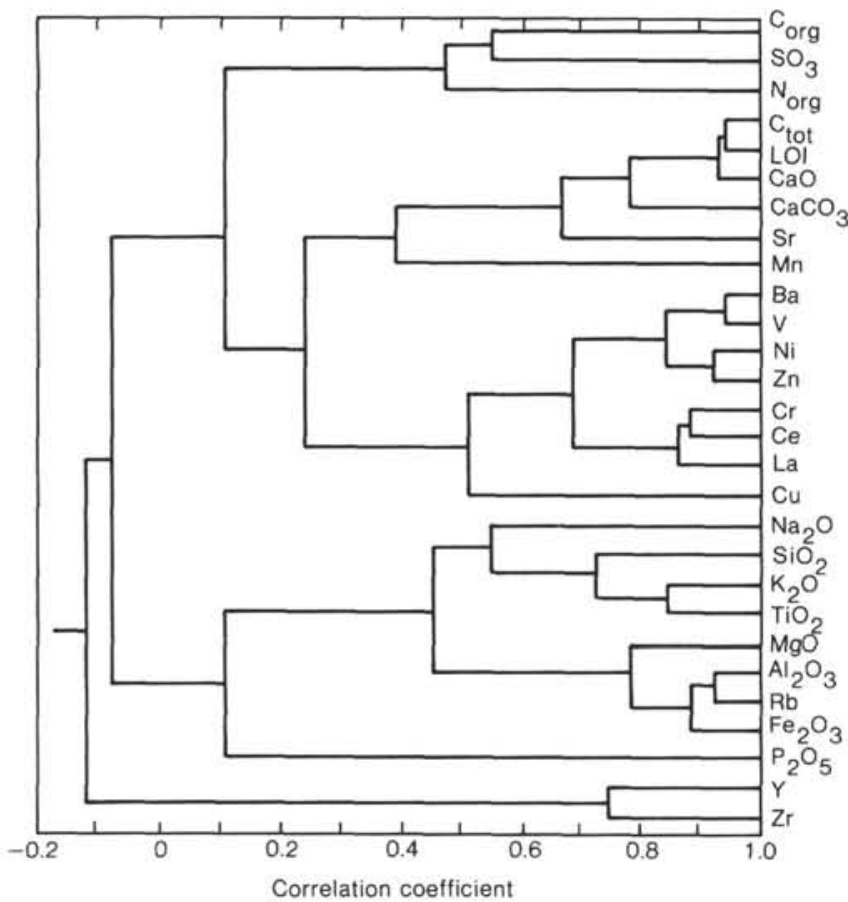

Figure 4. Dendrogram of cluster analysis for 33 sediment samples of Holes 603 and 603B. Given along the X-axis are correlation coefficients of parameter pairs.

the humic or kerogen fractions. One of the mechanisms which preserves carbohydrates by preventing their microbial degradation in the uppermost sediment layers is adsorption on charged clay mineral surfaces by hydrogen bonding or incorporation of functional groups into clay mineral interlayers (Lynch et al., 1956). No decrease of either total carbohydrates or their contribution to $\mathrm{C}_{\mathrm{org}}$ can be observed in sediments of Holes 603 and 603B (Table 4). Since the youngest sample is of Miocene age and was drilled at $222 \mathrm{~m}$ sub-bottom, we can assume that early diagenetic reactions have ceased, leaving residual material behind.

Variability in the distribution and abundance of this residual material must, then, have reasons other than diagenesis. Those samples where $\mathrm{CH}$-carbon of $\mathrm{C}_{\text {org }}$ accounted for more than $0.6 \%$ revealed typically marine-

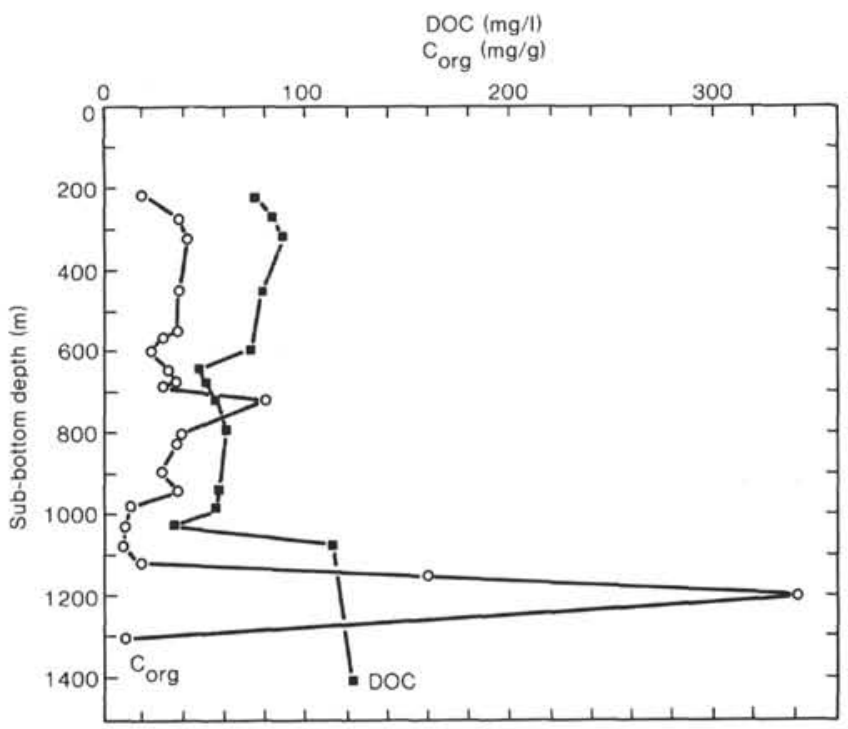

Figure 5. Dissolved organic carbon (DOC) in interstitial waters and corresponding $\mathrm{C}_{\text {org }}$ values in the sediment samples. DOC is given in $\mathrm{mg} / \mathrm{l}$ interstitial water, $\mathrm{C}_{\text {org }}$ is given in $\mathrm{mg} / \mathrm{g}$ sediment.

derived sugar spectra. These are composed of galactose, xylose, glucose, and mannose. Samples of purely marine detritus sampled by sediment traps (Ittekkot, Degens, et al., 1984; Ittekot, Deuser, et al., 1984) and Recent marine sediment samples (Degens et al., 1980) display a similar pattern in carbohydrate composition to sediments recovered at $220 \mathrm{~m}, 837 \mathrm{~m}$, and $1133 \mathrm{~m}$ at Site 603 . Sugar spectra indicate a dominant input and preservation of cell walls derived from marine plankton. These cell walls consist of heteropolysaccharides built by the monomeric sugars galactose, xylose, mannose, and rhamnose (Percival, 1979). In Figure 6, we plot total carbohydrates against depth, and to illustrate the absolute contributions of "marine" sugars, the shaded area gives the amount of galactose, xylose, mannose, and rhamnose. Arabinose, another important constituent of cell walls of marine algal heteropolysaccharides, is excluded from this plot, because of the unusual enrichment of this sugar observed in samples of Hole 603. This extraordinary enrichment cannot be explained by input of algal material alone. We assume that contributions of "marine" sugars exceeding $40 \%$ in Figure 6 indicate a typically marine origin of the corresponding organic matter.

Although our data are rather thinly distributed along the $1300 \mathrm{~m}$ of sedimentary column, a conspicuous cyclicity becomes apparent. Three cycles start with marine and end with terrestrial fingerprints $(200-700 \mathrm{~m}, 700-$ $1000 \mathrm{~m}$, and 1000-1300 m). "Terrestrial" spectra are characterized by the absence of "marine" sugars and contain relatively more glucose and arabinose (Hole 603), or glucose and fructose (Hole 603B). High relative amounts of glucose are expected from cellulose-rich organic matter from higher land plants and dominate sugar spectra when input is mainly terrestrial. High contents of fructose and glucose have been recognized in acid-hydrolizable extracts from continental and marine humic material (Spitzy, unpubl. data). 


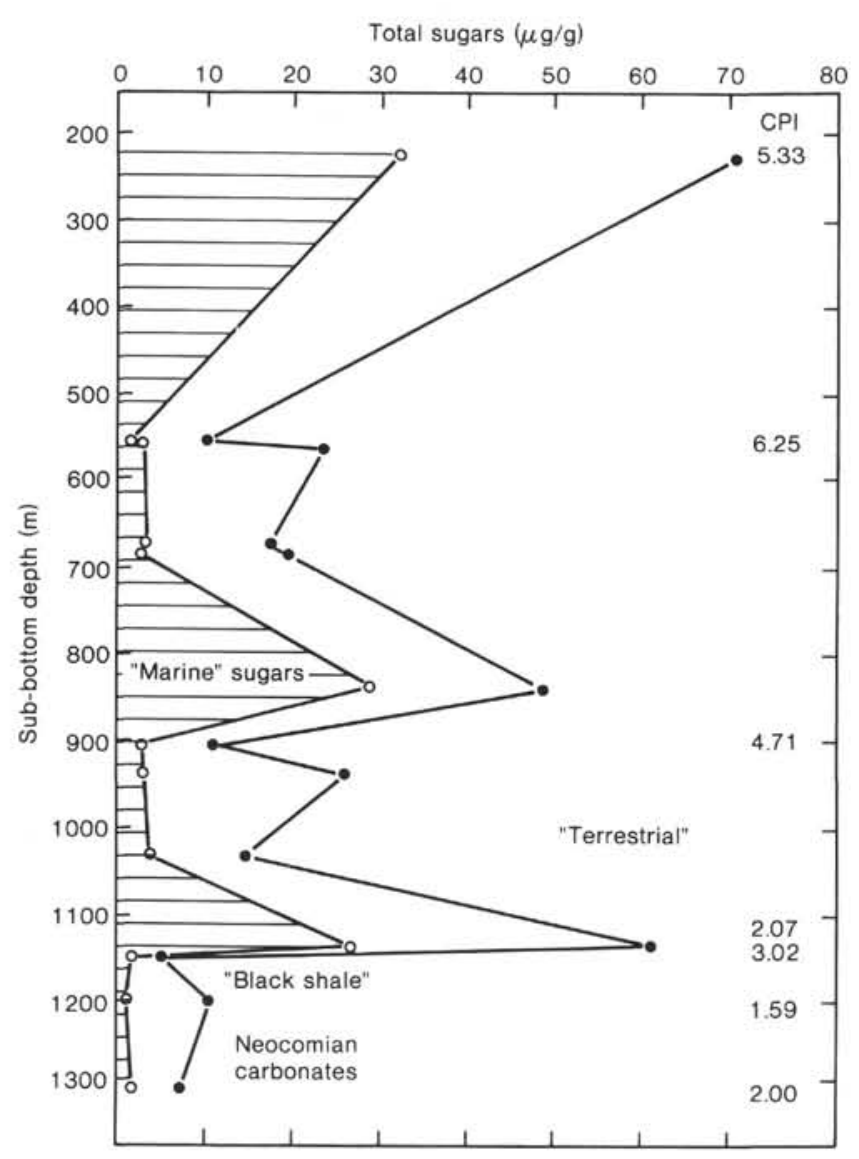

Figure 6. Concentrations of total sugars in the sediment versus depth. Shaded area gives the contribution of the "marine" carbohydrates galactose, xylose, mannose, and rhamnose to total sugars. Carbon preference indexes (CPI) from hydrocarbon extracts are given for some samples.

\section{Hydrocarbons}

To corroborate these interpretations, we added carbon preference indexes (CPI) for $n$-alkanes computed after Philippi (1965) in the plot to characterize lipid composition. $\mathrm{C}_{\mathrm{org}}, \mathrm{N}_{\mathrm{org}}$, and Rock-Eval studies given in the Site 603 site chapter (this volume) indicate a period of enhanced productivity in the Miocene. This coincides with the first $\mathrm{CH}$ maximum at $830 \mathrm{~m}$, whereas the second $\mathrm{CH}$ maximum at $930 \mathrm{~m}$ reflects a productivity change to conditions of poor preservation of organic matter. For the third marine $\mathrm{CH}$ maximum in the region of 1050 to 1200 , the zone of major black shale sedimentation, Rock-Eval analyses of equivalent sediments drilled during previous legs yielded high hydrogen indices (up to $600)$ representative of marine-derived organic matter (Herbin and Deroo, 1982). This finding is in concordance with the results of Deroo et al. (1980), who interpret this phase of enhanced marine carbon preservation encountered in western North Atlantic sediments as an indication of higher sedimentation rates.

Most samples analyzed for nonaromatic hydrocarbons during this study yielded high amounts of $n$-alkanes (Table 8). Chain lengths of 27,29 , and 31 carbon atoms predominate in all extracts, indicating a pronounced terrigenous input. A sharp decrease in the odd-carbon-num-
Table 8. Characteristics of hydrocarbon extracts, Site 603.

\begin{tabular}{cccccccc}
\hline $\begin{array}{c}\text { Sub-bottom } \\
\text { depth } \\
(\mathrm{m})\end{array}$ & $\begin{array}{c}\mathrm{C}_{\text {org }} \\
(\%)\end{array}$ & $\begin{array}{c}\text { Extr. HC } \\
(\mathrm{mg} / 100 \mathrm{~g} \mathrm{sed} .)\end{array}$ & $\begin{array}{c}\mathrm{mg} \text { extr./ } \\
\mathrm{g} \mathrm{C}_{\text {org }}\end{array}$ & $\begin{array}{r}\mathrm{mg} \mathrm{Hc} / \\
\mathrm{g} \mathrm{C}_{\text {org }}\end{array}$ & $\begin{array}{r}\mathrm{Pr} / \\
\mathrm{Ph}\end{array}$ & $\begin{array}{c}\mathrm{Pr} / \\
\mathrm{C}_{17}\end{array}$ & $\mathrm{CPI}^{\mathrm{a}}$ \\
\hline 222 & 0.21 & n.d. & n.d. & 4 & 1.95 & 0.77 & 5.33 \\
560 & 0.30 & 9.2 & 31 & 1 & 1.92 & 0.40 & 6.25 \\
902 & 0.28 & 13.6 & 49 & n.d. & 1.43 & 0.26 & 4.71 \\
1133 & 0.17 & n.d. & n.d. & n.d. & 1.01 & 1.53 & 2.07 \\
1149 & 1.61 & 122.2 & 76 & 27 & 2.22 & 1.10 & 3.02 \\
1200 & 3.18 & 329.0 & 103 & 11 & 1.73 & 0.78 & 1.59 \\
1299 & 0.10 & 10.0 & 100 & 6 & 2.18 & 3.86 & 2.00 \\
\hline
\end{tabular}

Note: Extr. $\mathrm{HC}$ are extractable hydrocarbons in $\mathrm{Tol} / \mathrm{MeOH} . \mathrm{Pr}=$ Pristane, $\mathrm{Ph}=\mathrm{Phy}$. tane, $\mathrm{n} . \mathrm{d}$. = no data.

a Carbon Preference Index, computed after Philippi (1965).

ber predominance of $n$-alkanes is recorded in extracts of sediments below $1000 \mathrm{~m}$. Two samples at $1133 \mathrm{~m}$ and $1299 \mathrm{~m}$ with low $\mathrm{C}_{\text {org }}$ contents yielded hydrocarbon spectra nearly devoid of $n$-alkanes. Pristane, phytane, steranes, and hopanes are the main constituents of the hydrocarbon fraction (see Fig. 7 and Table 9). The residual $n$-alkane distribution is qualitatively similar to those of neighboring sediments. This is interpreted as an indication of microbial degradation.

The pronounced odd-carbon-number preference observed in all samples, as reflected by CPI, is shown in Figure 6 and Table 8. Pristane/phytane ratios always exceed 1 , and mostly reach a value of 2 . Following the arguments of Didyk et al. (1978), this can be taken as an indication of oxic conditions in the depositional waters of the Mesozoic North Atlantic. Alternatively, microbial activity may significantly alter this ratio, thus restricting the validity of this indicator for the paleoenvironment. Pristane $/ \mathrm{C}_{17}$ ratios did not provide information about thermal evolution in these samples. The observed scatter in depth profiles of this ratio is partly explained by the biodegradation of $n$-alkanes, leading to increased values. Furthermore, isoprenoid hydrocarbons are preferentially released from kerogen because the bonds which attach these molecules to the macromolecular organic matter are relatively weak.

Jansa et al. (1979) suggested that "much of the calcareous and siliceous biogenic debris found locally within the Hatteras Formation probably had intermediate residence on shallow sea floor above the CCD (continental margin, mid ocean ridge flank, seamounts), before being rapidly emplaced in the deep basin by turbidity currents." The phenomenon of drastically increasing sediment nondeposition or removal around mid-Cretaceous time has been described by Ehrmann and Thiede (in press) for the western and eastern basins of the North Atlantic. Specific hiatus frequency of up to $45 \%$ was recorded at paleodepths of $2000-3000$ and $4000-5000 \mathrm{~m}$. We may assume that with a rather high position of the carbonate compensation depth (CCD) during the interval discussed here (Sclater et al., 1979), the allochthonous material encountered in mid-Cretaceous sediments is derived from sedimentary basins along the shelf or upper slope of the eastern North American margin.

The organic constituents of this material display characteristics of organic matter encountered in recent shelf and slope sediments (Premuzic, 1980). This material is a recycled, biodegraded mixture of marine and terrestrial 

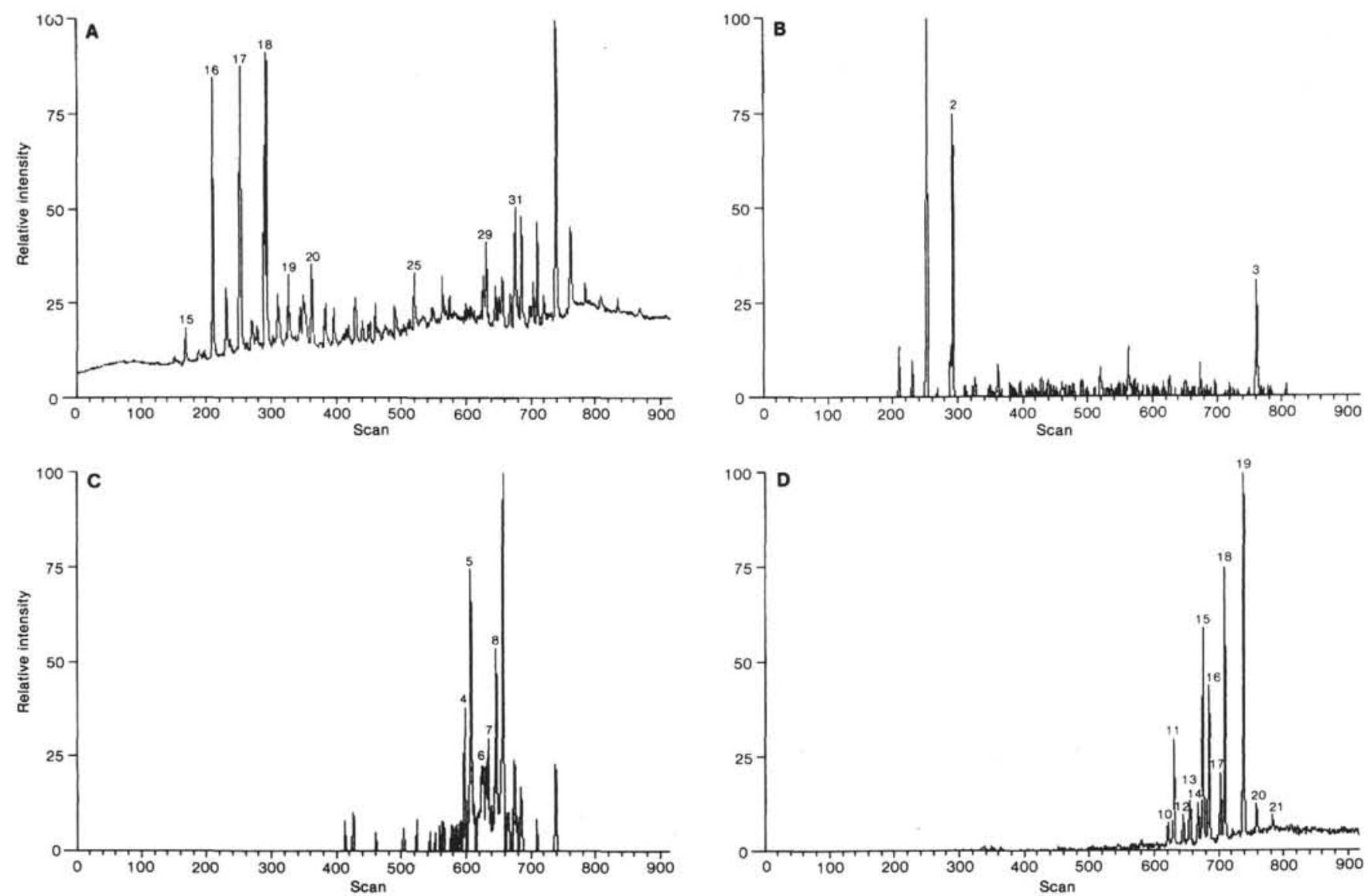

Figure 7. Organic geochemical analysis of a claystone sample (603B-36-3, $40 \mathrm{~cm}$ ). For identification of the numbered peaks in Figures 7B, C, and D refer to Table 9. A. Total ion chromatogram of the saturated hydrocarbon fraction separated from the total extract; $n$-alkanes are marked by their carbon numbers. B. selective ion current (SIC) of $\mathrm{m} / \mathrm{z} 183$ for the detection of acyclic isoprenoid hydrocarbons. C. SIC of m/z 217 for the detection of steroid hydrocarbons. D. SIC of $\mathrm{m} / \mathrm{z} 191$ for the detection of triterpenoid hydrocarbons. Scan is time measured in GC-MS runs.

Table 9. Compounds detected in hydrocarbon extracts by GC-MS.

Acyclic isoprenoids:

$$
\begin{aligned}
& \text { Pristane } \\
& \text { Phytane } \\
& \mathrm{C}_{30} \text { isoprenoid (unknown) }
\end{aligned}
$$

Steroids:

$$
\begin{aligned}
& 5 \beta(\mathrm{H}) \text {-cholestane } \\
& 5 \alpha(\mathrm{H}) \text {-cholestane } \\
& 24 \text {-methyl- } 5 \beta(\mathrm{H}) \text {-cholestane } \\
& \text { 24-methyl- } 5 \alpha(\mathrm{H}) \text {-cholestane } \\
& \text { 24-ethyl- } 5 \beta(\mathrm{H}) \text {-cholestane }
\end{aligned}
$$$$
\text { 24-ethyl-5 } \alpha(\mathrm{H})-\mathrm{cholestane}
$$

Hopanoids:

$$
\begin{aligned}
& 17 \alpha(\mathrm{H}) \text {-trisnorhopane } \\
& 17 \beta(\mathrm{H}) \text {-trisnorhopane } \\
& \left.\mathrm{C}_{30} \text { triterpane (unknown: } \mathrm{m} / \mathrm{z} 414\right) \\
& 17 \alpha(\mathrm{H}) \text {-norhopane } \\
& \text { normoretane } \\
& 17 \alpha(\mathrm{H}) \text {-hopane } \\
& 17 \beta(\mathrm{H}) \text {-norhopane }(+ \text { minor moretane) } \\
& 17 \alpha(\mathrm{H}) \text {-homohopane } \\
& 17 \beta(\mathrm{H}) \text {-hopane (+minor homomoretane) } \\
& 17 \beta(\mathrm{H}) \text {-homohopane } \\
& 17 \beta(\mathrm{H}) \text {-bishomohopane } \\
& 17 \beta(\mathrm{H}) \text {-trishomohopane }
\end{aligned}
$$

provenance. Intermittently, input of this material is significant. Because of their $\mathrm{C}_{\text {org }}$ content, maturity, and kerogen composition, these strata may well be interesting source rocks for hydrocarbon exploration

\section{ACKNOWLEDGMENTS}

Financial support provided by the Deutsche Forschungsgemeinschaft throughout this study is gratefully acknowledged. The manuscript profited considerably from helpful criticism by reviewers Drs. W. Dean, D. A. Dunn, and B. R. T. Simoneit.

\section{REFERENCES}

Chamley, H., Debrabant, P., Candillier, A.-M., and Foulon, J., 1983. Clay mineralogical and inorganic geochemical stratigraphy of BlakeBahama Basin since the Callovian, Site 534, Deep Sea Drilling Project Leg 76. In Sheridan, R. E., Gradstein, F. M., et al., Init. Repts. DSDP, 76: Washington (U.S. Govt. Printing Office), 437-451.

Cook, H. E., Johnson, P. D., Matti, J. C., et al., 1975. Methods of sample preparation and X-ray diffraction data analysis, X-ray Mineralogy Laboratory, Deep Sea Drilling Project, University of California, Riverside. In Hayes, D. E., Frakes, L. A., et al., Init. Repts. DSDP, 28: Washington (U.S. Govt. Printing Office), 999-1007.

Dean, W. E., Arthur, M. A., and Stow, D. A. V., 1984. Origin and geochemistry of Cretaceous deep sea black shales and multicoloured claystones, with emphasis on Deep Sea Drilling Project Site 530, southern Angola Basin. In Hay, W. W., Sibuet, J.-C., et al., Init. Repts. DSDP, 75: Washington (U.S. Govt. Printing Office), 819-844. 
Degens, E. T., Emeis, K.-C., Mycke, B., and Wiesner, in press. Geochemical comparison between North and South Atlantic organicrich sediments: Paleoenvironmental implications. Proc. North Atlantic Palaeoceanography Meeting, London.

Degens, E. T., Garrasi, C., Mopper, K., Kempe, S., and Ittekkot, V., 1980. Warven-Chronologie und frühdiagenetische Umsetzung organischer Sedimente des Schwarzen Meeres. N. Jb. Geol. Paläont. Mh., 1980, pp. 65-86.

Deroo, G., Herbin, J. P., Roucaché, J., and Tissot, B., 1980. Organic geochemistry of Cretaceous sediments at DSDP Holes 417D (Leg 51), 418A (Leg 52), and 418B (Leg 53) in the western North Atlantic. In Scientific Party, Init. Repts. DSDP, 51, 52, 53, Pt. 2: Washington (U.S. Govt. Printing Office), 737-745.

Didyk, B. M., Simoneit, B. R. T., Brassell, S. C., and Eglington, G., 1978. Organic geochemical indicators of paleoenvironmental conditions of sedimentation. Nature, 272:216-222.

Ehrmann, W. U., and Thiede, J., in press. History of Mesozoic and Cenozoic sediment fluxes to the North Atlantic Ocean. Contrib. Sedimentol.

Emeis, K.-C., 1985. Geochemie von Schwarzschiefern und organischreichen Sedimenten des Atlantischen Ozeans [Ph.D. dissert.]. University of Hamburg.

Graybeal, A. L., and Heath, G. R., 1984. Remobilization of transition metals in surficial pelagic sediments from eastern Pacific. Geochim. Cosmochim. Acta, 48: 965-975.

Gutjahr, C. C. M., 1983. Introduction to incident-light microscopy of oil and gas source rocks. Geol. en Mijnbouw, 62:417-425.

Hérbin, J. -P., and Dèroo, G., 1982. Sédimentologie de la matière organique dans les formations du Mésozoîque de l'Atlantique Nord. Bull. Soc. Geol. France, 7(24):497-510.

Ittekkot, V., Degens, E. T., and Honjo, S., 1984. Seasonality in the fluxes of sugars, amino acids and amino sugars to deep ocean: Panama Basin. Deep-Sea Res., 31:(9A):1057-1063.

Ittekkot, V., Deuser, W. G., and Degens, E. T., 1984. Seasonality in the fluxes of sugars, amino acids and amino sugars to deep ocean: Sargasso Sea. Deep-Sea Res., 31(9A):1064-1071.

Jansa, L. F., Enos, P., Tucholke, B. E., Gradstein, F. M., and Sheridan, R. E., 1979. Mesozoic-Cenozoic sedimentary formations of the North American Basin; western North Atlantic. In Talwani, M. M., Hay, W. W., and Ryan, W. B. F. (Eds.), Deep Drilling Results in the Atlantic Ocean: Continental Margins and Paleoenvironment. Am. Geophys. Un., Maurice Ewing Ser., 3:1-57.

Leinen, M., and Pisias, N., 1984. An objective technique for determining end-member compositions and for partitioning sediments according to their sources. Geochim. Cosmochim. Acta, 48:47-62.

Le Pichon, X. and Sibuet, J.-C., 1981. Passive margins: a model of formation. J. Geophys. Res., 86:3708-3720.

Lynch, D. L., Wright, L. M., and Cotnoir, L. J., 1956. The adsorbtion of carbohydrates and related compounds on clay minerals. Soil Sci. Soc. Proc., 1956:6-9.

Meyers, P. A., in press. Organic geochemistry of Mesozoic organic carbon-rich shales and limestones from the western North Atlantic. Proc. North Atlantic Palaeoceanography Meeting, London.
Michaelis, W., Mycke, B., Vogt, J., Schütze, G., and Degens, E. T., 1982. Organic geochemistry of interstitial waters, Sites 474 and 479, Leg 64. In Curray, J. R., Moore, D. G., et al., Init. Repts. DSDP, 64, Pt. 2: Washington (U.S. Govt. Printing Office), 933937.

Mopper, K., 1978. Improved chromatographic separations on anion exchange resins, III: sugars in borate medium. Anal. Biochem., $87: 162-168$.

Müller, P. J., 1977. C/N ratios in Pacific deep-sea sediments: effect of inorganic ammonia and organic nitrogen compounds sorbed by clays. Geochim. Cosmochim. Acta, 41:765-776.

Mycke, B., Emeis, K.-C., and Degens, E. T., 1986. Diagenesis of organic compounds in Hole 593, Leg 90 (Tasman Sea). In Kennett, J. P., von der Borch, C. C., et al., Init. Repts. DSDP, 90: Washington (U.S. Govt. Printing Office), 1265-1272.

Ottenjann, K., 1982. Verbesserungen bei der mikroskophotometrischen Fluoreszenmessung an Kohlemaceralen. Zeiss Information, 26(93):40-46.

Percival, E., 1979. The polysaccharides of green, brown, and red seaweeds: their basic structure, biosynthesis and function. Br. Phycol. J., 14:103-117.

Philippi, G. T., 1965. On the depth, time, and mechanism of petroleum generation. Geochim. Cosmochim. Acta, 29:1021-1049.

Premuzic, E. T., 1980. Organic carbon and nitrogen in the surface Sediments of World Oceans and Seas: Distribution and Relationship to Bottom Morphology. Brookhaven National Laboratory Rep. No. 51084.

Redfield, A. C., Ketchum, B. H., and Richards, F. A., 1963. The influence of organisms on the composition of seawater. In Hill, M. N., (Ed.), The Sea: New York (Interscience), pp. 26-87.

Sclater, J. G., Boyle, E., and Edmond, J. M., 1979. A quantitative analysis of some factors affecting carbonate sedimentation in the ocean. In Talwani, M., Hay, W. W., and Ryan, W. B. F., (Eds.), Deep Drilling Results in the Atlantic Ocean: Continental Margins and Paleoenvironment. Am. Geophys. Union, Maurice Ewing Ser., 3:235-248.

Tanoue, E., and Handa, N., 1979. Different sorbtion of organic matter by various sized particles in recent sediment from the Bering Sea. J. Oceanogr. Soc. Japan, 35:199-208.

Teichmüller, M., and Ottenjann, K., 1977. Art und Diagenese von Liptiniten und lipoiden Stoffen in einem Erdölmuttergestein aufgrund fluoreszenzmikroskopischer Untersuchungen. Erdöl Kohle, 30:387-398

Überla, K., 1977. Faktorenanalyse (2nd ed.): Heidelberg (Springer).

Wedepohl, K. H. (Ed.), 1978. Handbook of Geochemistry: Heidelberg (Springer).

Wise, S. W., and Leg 93 Shipboard Party, in press. Mesozoic-Cenozoic clastic depositional environments revealed by DSDP Leg 93 on the continental rise off the eastern United States. Proc. North Atlantic Palaeoceanography Meeting, London.

Date of Initial Receipt: 5 February 1985

Date of Acceptance: 9 October 1985 